\title{
EL LUGAR DE LOS PARQUES NACIONALES EN LA REPRESENTACIÓN DE UNA PATAGONIA TURÍSTICA, DISCUSIÓN Y HABILITACIÓN DEL PAISAJE PATAGÓNICO DURANTE EL SIGLO XX
}

GABRIELA ÁLVAREZ G.

\begin{abstract}
RESUMEN
Nos interesa indagar los momentos claves de cómo el turismo interviene en los procesos de representación del imaginario patagónico a partir del siglo XX. En especial, las narraciones que declaran a la zona patagónica en un sitial de preponderancia nacional e internacional (en el horizonte económico y turístico). Primero, describiremos un esquema general de los desafíos del turismo contemporáneo. Segundo, reconoceremos el discurso del turismo presente en las discusiones y actos que habilitaron los parques nacionales en Argentina y Chile. Observar qué prácticas sociales sugirieron lo "digno" de ver, cómo se estructuró la imagen de la Patagonia turística y quiénes participaron, son algunas de las interrogantes que nos proponemos rastrear en este trabajo.
\end{abstract}

PALABRAS CLAVE: turismo, Patagonia, parques nacionales.

\section{THE PLACE OF NATIONAL PARKS IN THE REPRESENTATION OF A TOURIST PATAGONIA. THE PROCESS OF DISCUSSION AND QUALIFICATION OF PATAGONIAN LANDSCAPE DURING THE TWENTIETH CENTURY}

\begin{abstract}
Our interest is to investigate the key moments of how tourism is involved in the processes of imaginary representation of Patagonia from the twentieth century onward. In particular, narrations that declare Patagonia region in a place of national and international prominence (on the economic horizon and tourism). First, we describe a summary of the challenges of contemporary tourism. Second, to recognize the discourse about tourism in the discussions and actions that enabled national parks in Argentina and Chile. What social practices suggested as "worthy" to see, how the image of the Patagonian tourist was organized, and who participated, are some questions to answer in this paper.
\end{abstract}

KEY WORDS: tourism, Patagonia, national parks.

Doctorado del Programa de Estudios Americanos, Universidad de Santiago, Chile. Becaria CONICYT. gabrielaalvarez5121@ hotmail.com. 


\section{LAS PARTICULARIDADES Y LOS REQUERIMIENTOS DEL TURISMO CONTEMPORÁNEO}

La geografía fue la puerta de entrada para conocer las características centrales de la Patagonia. La seguidilla de descripciones en bitácoras e informes de viaje, sea cual sea su origen, aumentó el imperativo de que la Patagonia se vincule al gesto de la contemplación. Miradas que moldean sus orillas y como fueron siglos de relevamientos, los discursos se constituyeron en marcos descriptivos difíciles de omitir, y la palabra recrea sin pausa, un imaginario con el suficiente espesor para la zona. Imaginarios que sin duda se mueven. Quien iba a pensar que los mismos canales causantes de los estragos en varias embarcaciones, actualmente son liquidados al mejor postor por las agencias de viaje que promueven maravillosas panorámicas en sus folletos turísticos. El mar se tranquilizó pasado los siglos o bien, el paisaje y su gente son rearticulados en un aparataje discursivo complejo, como destacar la soledad contemplativa de los témpanos, sin olvidar su movimiento estruendoso y agresivo, o la osadía y el carácter taciturno del poblador y su amabilidad pausada hacia todo extranjero.

Cada verano en nuestro país, observamos la revisita de los reportajes de viaje a "las maravillas del sur". Paisajes atrayentes desde la perspectiva de la economía interna, por las cuantiosas divisas que generan la visita de extranjeros y connacionales, que eligen este punto del territorio como itinerario de sus descansos. Si nos concentramos sólo en el sentido del viaje, antes del siglo XX era un acto marginal, cuya práctica era poco predecible o calculable. Hoy con el turismo, evidencia una necesidad global en la economía doméstica, capaz de propiciar otras actividades productivas importantes en la planificación pública de cada país. En otras palabras, desde tiempos memoriales el sujeto ha viajado hacia otros lugares motivado por la guerra, la migración, la religión, etc.; sin embargo, existe un acuerdo general en las distintas disciplinas que estudian el turismo, que éste como discurso y práctica social, se articuló durante el siglo XX y con criterios sistemáticos después de los años cincuenta, con la declaración del turismo de masas.

Normalmente el turismo es materia de interés en los debates económicos vinculados a la gestión sobre el ingreso y egreso de visitantes puesto que, son miles de personas en el mundo las que consumen espacios de forma temporal. Desde 1925, este criterio se oficializa con el apoyo de la Organización Mundial del Turismo que define y promueve su crecimiento en todos los países:

La OMT, como principal organización internacional en el ámbito turístico, aboga por un turismo que contribuya al crecimiento económico, a un desarrollo incluyente y a la sostenibilidad ambiental, $y$ ofrece liderazgo y apoyo al sector para expandir por el mundo sus conocimientos y políticas turísticas (Organización Mundial del Turismo, 2012).

El turismo para la organización: comprende las actividades que realizan las personas durante sus viajes y estancias en lugares distintos a su entorno habitual, por un periodo de tiempo consecutivo inferior a un año, con fines de ocio, por negocios y otros (Sancho \& Duhalis, 1998:11). La OMT recalca la importancia del turismo como práctica social a partir de los años 50. El neoliberalismo influye en el aumento sin pausa de la industria, integrado a un sistema capaz de medir la oferta, la demanda y los espacios geográficos.

Las principales investigaciones sobre el turismo provienen del área de la geografía y la economía; no obstante, en los últimos años la sociología y la antropología han investigado el fenómeno turístico en la medida que interviene en las lógicas internas de una sociedad. Sin agotar la discusión, presentaremos un esquema general de los desafíos actuales del turismo.

Daniel Hiernaux sintetizó las principales orientaciones relativas al estudio del turismo. El área legal, comprende la normativa laboral que regula el tiempo libre de los trabajadores con las vacaciones; asimismo, la disposición internacional constituye una pauta definitoria de los derechos y obligaciones del turista; sin embargo, los cambios en las sociedades contemporáneas (el descanso en los trabajadores independientes, la flexibilidad laboral o la renuncia a las vacaciones), son situaciones que parecen no tomar en cuenta estos marcos jurídicos. En la economía, el hecho turístico es identificado dentro de los procesos micro y macro 
a nivel económico: estos se basan sobre el hecho de que los gigantescos flujos de personas para fines turísticos, arrastran con ellos desplazamientos no menos sustanciales de recursos, inversiones o gastos y de demanda agregada que genera, a su turno, oferta agregada (Hiernaux, 2002:17-18); no es extraño su trasvasije hacia el discurso político defensor de las inversiones por los beneficios en este campo. Por su parte, la ciencia administrativa, formula abstracciones del turismo como la gestión y el manejo de empresa (rentabilidad, satisfacción del cliente, otros). La sociología en cambio, sobrepasa la relación tiempo libre/trabajo porque considera que el turismo es más que la administración del tiempo sobrante, situarlo en un sistema de poder $y$ observar sus efectos en las sociedades son desafíos importantes en la práctica turística. Por último, el estudio geográfico, considera dos criterios en la comprensión del movimiento turístico: los flujos y los destinos turísticos como las dimensiones y el carácter espacial en las actividades turísticas. Hiernaux considera que el turismo es un inductor de actividades económicas; por lo mismo, comprende su desarrollo dentro de una línea multidisciplinaria que defina más cabalmente sus puntos centrales:

El turismo es un proceso societario que se originó en el mundo occidental a partir del siglo XIX y en forma masiva durante la segunda mitad del siglo XX. Este proceso partió de una redefinición de los tiempos sociales [...] Este proceso societario se caracteriza, además, por sus profundos impactos en la economía a escala macro y microeconómica, así como a escala macro y microespacial. Induce también cambios sociales en los lugares de destino, tanto como en los lugares que emiten los turistas (Hiernaux, 2002: 27).

Margarita Barreto tomó en cuenta la cultura turística más que una definición encapsulada en una disciplina, es decir mirar el turismo en espacios y prácticas específicas y la forma de desenvolverse en una sociedad determinada. El objetivo era demostrar la heterogeneidad de circunstancias en el desarrollo del turismo, sin olvidar las contradicciones en el escenario presente como la densidad de viajeros, el problema medioambiental y la resistencia local, etc. Según lo dicho, el turismo es un campo complejo, difícil de encasillar en un modelo que englobe sus principales desafíos en cada organización social. Si el turismo no encaja totalmente en una estructura unívoca entonces afirma la autora, aceptemos el concepto de rizoma porque emergen situaciones inabarcables en una reducida cerca analítica:

El turismo es un fenómeno que crece y se expande de forma bastante incontrolable e imprevisible a través del tiempo y del espacio. En cada momento y lugar en que se produce el fenómeno turístico se producen una serie de relaciones que siempre son, en algún grado, diferentes y nunca totalmente predecibles. Así como un brote de una planta rizomática nunca es idéntico a otro, las situaciones de turismo no se reproducen, ni siquiera en el turismo llamado técnicamente de "masas", caracterizado por su fidelidad a ciertos modelos estandarizados de comportamiento (Barreto, 2007:13).

Barreto examina un sinnúmero de experiencias turísticas en varios países que confirma su tesis del carácter heterogéneo y de las relaciones interconectadas del turismo, más que la existencia de un tronco homogéneo. Otros temas complementan este estudio: las desventajas del sistema turístico (la desvinculación con la sociedad, la ausencia de políticas integrales y el desgaste espacial), los beneficios (la conservación del patrimonio, la ampliación del conocimiento y la valoración del espacio), y el nivel de conflictos entre el visitante y la comunidad receptora (los estereotipos, la representación de la autenticidad y la desconexión con el otro).

Por su parte, Jafar Jafari, repasa temporalmente los discursos académicos vinculantes con el tema, con el fin de afirmar su superioridad en la industria mundial. Así, agrupa las lecturas que han dado un peso cognoscitivo en el camino de constituir una disciplina científica:

a) La plataforma apologética: Confía en los resultados estadísticos del éxito del turismo en el crecimiento del empleo, la preservación del patrimonio, el refuerzo de la identidad cultural etc.

b) La plataforma precautoria: $\mathrm{El}$ auge económico producto del turismo es criticado en los años 60', porque sus beneficios son 
para los grandes capitales y la localidad se empobrece con el desmantelamiento de sus oficios tradicionales, el aumento de la monoactividad y los empleos estacionales.

c) La plataforma adaptativa: Es un camino intermedio de los dos programas anteriores, ya que denuncia los impactos del turismo como la mención de opciones respetuosas con la cultura local.

d) La plataforma científico-céntrica: A fines del siglo XX, el rumbo elegido fue analizar de manera global la composición formal del área turística con el objeto de edificar: un cuerpo científico de conocimiento sobre el turismo (Jafari, 2005:43).

e) La plataforma de interés público: Es una línea emergente preocupada por demostrar el grado de legitimidad del turismo frente a otros canales productivos. La meta es demostrar que su éxito lucrativo se traduce en un prestigio evidente dentro de las políticas públicas de cada país.

Más allá de los cuestionamientos disciplinarios es importante entender las particularidades del turismo contemporáneo. Precisamente Erik Cohen, enuncia las tendencias actuales del turismo en un contexto donde los grandes relatos se desmantelan y un sujeto fragmentado se dispersa en los paisajes del mundo. Cohen retoma la relación turismo y modernidad y lo adapta a la situación presente de las sociedades (cada día más posmoderna). En el paradigma moderno, el turista demuestra en sus acciones, las características básicas de ésta; por ejemplo, el deseo obsesivo de encontrar la alteridad -la autenticidad/el margen de lo moderno-; el viaje turístico se comportaría como un elemento compensatorio de lo extraviado en la vida moderna. No obstante, Cohen observa la contradicción de esta fórmula porque los destinos turísticos (lugares y personas), suponen una transformación en el mismo momento en que son elegidos como rutas de viaje, pues responden a un conjunto de reglas del sistema turístico que difunde atracciones y vistas carentes de autenticidad. Por lo tanto, el sujeto turístico generalmente está frente a representaciones manifiestas (construcciones deliberadamente creadas para tal efecto) o autenticidades representadas (representaciones falseadas de una práctica cultural): el fenómeno del turismo en un mundo cada vez más homogeneizado y regulado, las atracciones representadas juegan claramente un rol cada vez más dominante; $y$ entre tales atracciones, aquellas basadas en temas imaginarios y auto referenciales son particularmente importantes -de hecho, la sofisticada tecnología contemporánea permite crearlas con un grado de realismo aparente que llega a ser "hiperreal"(Cohen, 2005:14).

Aceptar sin conflicto el simulacro de dibujar (o desdibujar) lo real, convierte el viaje en la metáfora dominante, pero el tránsito hacia la homogenización turística reduce la atención del mismo atractivo, el problema es cómo el turista debe asumir tal contexto. El autor sugiere tres formas potenciales del comportamiento del turista correspondiente a la visión posmoderna del mundo, que se suma a las principales tendencias del turismo contemporáneo. Primero, renunciar de antemano a encontrar la experiencia auténtica o extraordinaria a través del viaje (el sujeto "postturista"):

Los "post-turistas" no se preocupan de lo genuino y puede que prefieran el sucedáneo a lo auténtico si es más agradable, más «bonito» o más cómodo: la piscina al mar, las flores artificiales a las naturales, la copia accesible o bien hecha al original difuso y distante. Prefieren lo kitsch al arte, incluso dado que los limites entre estos dominios culturales son cada vez más difusos, lo kitsch es incluso más artístico, el arte (irónicamente) imita lo kitsch (Cohen, 2005:16).

Segundo, la falta de lo auténtico se compensa con la elección de lo extraordinario mediatizado por una tecnología constructora de hiperrealidades como son los parques temáticos en EEUU y Europa. Tercero, desafiar la idea totalizante de la ausencia de lo auténtico y evadir los marcos turísticos para ir en su búsqueda, trabajo que implica recorrer circuitos lejanos del sistema turístico.

Para el autor, la distinción en el consumo revela el lugar social y el capital cultural que posee el turista. Un sujeto inmerso en la novedad de los espectáculos musicales, artísticos, teatrales, etc., describe a una subjetividad comprometida 
con la cultura global contemporánea que con la desaparición étnica de un grupo social. Por otro lado, disfrutar de la fantasía es un espacio de resistencia a los embates de la homogenización posmoderna, la inclusión de las singularidades del lugar en los parques temáticos o convertir la experiencia extrema en espectáculo, es parte de esta manifestación.

John Urry también exploró los atributos del turismo contemporáneo con el análisis de la mirada turística, a través de un repaso por los distintos periodos históricos y los grupos sociales. Investigación que indaga qué o quiénes autorizan tal mirada, sus efectos en los lugares y si existe una interrelación con otras prácticas sociales. El autor no define una experiencia universal turística porque existe un contexto histórico que la circunscribe, aunque si registra las características mínimas del turismo, coincidente con las propuestas de los autores ya mencionados:

- El turismo es una actividad normada que presupone dos situaciones sociales que se organizan de forma separada: el ocio y el trabajo.

- Las relaciones turísticas involucran el movimiento de personas en un espacio específico y en un periodo temporal determinado. Los fines del viaje generalmente no se conectan con las ocupaciones laborales sino con su cara opuesta el descanso reglamentado.

- El sueño y la fantasía complementan la elección de un destino turístico porque lo anticipan prácticas sociales no propias del turismo: el cine, los documentales y la fotografía construyen los atributos espaciales y refuerzan la mirada turística.

- Los aspectos considerados fuera de lo normal son transformados en "vistas" $y$ su visualización implica muchas veces, patrones sociales distintos del viajero. Luego de mirar, prosigue la captura visual con fotografías, postales, películas, etc., una mirada construida por signos que suponen una y otra vez su reproducción: the gaze is constructed through signs, and tourism

1 La mirada se construye a través de los signos, y el turismo acumula signos. Cuando los turistas ven dos personas besándose en Paris, lo que capturan en la mirada es "una involves the collection of signs. When tourists see two people kissing in Paris what they capture in the gaze is "timeless romantic Paris. When a small village in England is seen, what they gaze upon is the "real old England ${ }^{1}$ (Urry, 2002:3).

- Los organismos y profesionales del turismo siempre aspiran a reproducir nuevos objetos para la mirada del turista. Hechos que dependen de distintos factores. Entre ellos, la interacción de los deseos implicados en la generación del objeto y los cambios en la sociedad (clase, género y generacional), materias convenientes para distinguir el gusto potencial de la población visitante.

Retornemos al punto inicial: el turismo y los momentos de intervención directa e indirecta en la representación turística de la Patagonia en el siglo $\mathrm{XX}$. En especial, los correlatos que exponen a la Patagonia en un sitial de preponderancia nacional e internacional por considerarla un producto exportable, un paisaje valorable y una geografía sorprendente, que concentra el deseo de una zona inagotable. Interrogar qué prácticas sociales sugirieron lo "digno" de ver, cómo se estructuró la imagen turística y quiénes participaron, son parte de la batería de preguntas que conlleva este trabajo.

El número de atractivos turísticos en la Patagonia actualmente es considerable; por lo tanto, acotaremos el trabajo en las discusiones y acciones que participaron en la construcción de los parques nacionales en esta zona geográfica. Para ello, en primera instancia observaremos la experiencia de EEUU en la formación de este discurso, particularmente los argumentos favorables a la idea de la nación y los debates de conservación del medio ambiente y posteriormente, indicar las posibles conexiones e influencia en la instalación de los primeros parques nacionales en Chile y Argentina. En la Patagonia Argentina nos centraremos en el Parque Nacional Nahuel Huapi, con el objetivo de resaltar de los estudios desarrollados, las temáticas que subrayan los planes de estructuración y el proceso de articulación en atractivo turístico. Aquí la intervención de las distintas instituciones del Estado fue fundamental

escena romántica parisina atemporal". Cuando ven un pequeño pueblo de Inglaterra, lo que contemplan es la "real vieja Inglaterra". 
para delimitar sus límites geográficos y su lugar en los intereses nacionales; tareas que sin duda derivó en una práctica social y en un mecanismo de representación. En la zona de Magallanes en cambio, destacamos el Parque Nacional Torres del Paine. La revisión bibliográfica nos da como resultado, que son casi nulas las investigaciones que describen el papel de las instituciones estatales en su habilitación o los argumentos iniciales respecto a la importancia para el país de proteger un área natural como los territorios aledaños al Paine. Tampoco existe una mención especial en la reseña de la formación del parque, de las tareas llevadas a cabo por los actores locales en el proceso de su construcción. La mayoría de los trabajos se ubican en la clasificación de las especies y manejo de los suelos, el impacto económico y social en las ciudades de Punta Arenas y Puerto Natales $y$ últimamente, se abocan en las consecuencias generadas por los consecutivos incendios en la flora y la fauna, junto a las tareas pendientes en los mecanismos de seguridad y las sugerencias en las operaciones turísticas dentro del parque. Entonces, queremos ubicar algunas señales de rutas que nos permitan reconstruir algunos momentos a nivel de representación, de cómo un entorno natural se transformó en atractivo turístico. Tareas en las que se apoyó una práctica específica y una manera de representarla, que implicó la exploración, encuadre y montaje de imágenes como el de resaltar ciertos elementos del paisaje. Este punto lo dividimos en tres instancias: el viaje de ocio y caza de la comitiva inglesa a fines del siglo XIX, transcrito en el diario de Florence Dixie, la enmarcación fotográfica de los macizos del Paine por Alberto de Agostini y el potencial turístico impulsado por los organismos locales como el Touring Club de Punta Arenas.

\section{LOS NEXOS ENTRE NACIÓN Y TERRITORIO EN LA CREACIÓN DE LOS PARQUES NACIONALES. LOS DEBATES CONSERVACIONISTAS EN EEUU Y SU INFLUENCIA EN LATINOAMÉRICA}

La Patagonia se incorporó en el poderío estatal mediante el resultado de acciones violentas $e$ invasivas, contra aquello no concordante con el relato progresista del Estado y la oligarquía sureña. La extensión de la frontera interna por la Campaña del Desierto en Argentina y la expropiación de terrenos junto a la anulación silenciosa -igual de brutal- por parte del Estado chileno, adelantaron un escenario perfecto en la manera de organizar la sociedad presente y futura. La entrada del siglo XX, reguló la sociedad patagónica según las demandas de una economía cuya explotación ha sido el suelo; la conquista simbólica y política fijó el control de extensos territorios que en pocos decenios consolidó una pauta hegemónica, que anuló otros modos de apropiación del espacio. Acciones que se trasladó a la manera de representar la Patagonia, que en resumen abarcaría un examen entrecruzado de textos y contextos desde el siglo XVI, en la cual se agrupan las cualidades de desierto, esterilidad y monstruosidad en una línea narrativa continuista. A partir del siglo XIX, la inclusión de la retórica progresista particularmente en los discursos científicos y políticos, reconfiguran este sentido en función a la emergencia de los estados nacionales. La categoría de desierto se extiende entonces, hacia los indígenas para enfatizar su ausencia (restos) y asimismo, interesarse en las grandes extensiones de territorio ("sin dueños"), promoviendo a nivel de representación, la idea de que sus habitantes originarios se ubican fuera de este relato por su carácter de salvaje e incivilizado.

Precisamente, los mecanismos de apelación al pionero marcharon con éxito cuando el sujeto logró experimentar en la concreción de ciudades y pueblos, que las promesas del modelo agroexportador fueron palpables en su cotidianidad más inmediata. Esquema que expresa en sus calles, la bonanza de un modelo que rápidamente estableció lazos de identificación con los recientes habitantes pero, la alteración económica internacional (el periodo entre guerras), suscitó la caída en las exportaciones que derivó en una crisis en los años 30. El turismo es una temática interesante porque ofreció una opción a los organismos estatales, de valorizar las estampas patagónicas con nuevos criterios económicos. Especialmente desde el siglo $\mathrm{XX}$, la transformación paulatina de los espacios en objeto de exportación turística, ha reportado millones de dólares, pese a que la distribución de sus divisas continúe deficiente en el seno de las comunidades locales.

La colonización avanzó a pasos agigantados, aun así sobresalen argumentos acerca de la 
obligación de mantener fragmentos territoriales bajo el control estatal, con el objeto de conservar la naturaleza para la posteridad. Durante este periodo entonces, los países latinoamericanos debatieron acerca de temas correspondientes a la valorización, delimitación y protección de los espacios naturales, en continuidad con la experiencia de EEUU, precursor en la gestación y validación de los llamados parques nacionales.

La expansión de la frontera de EEUU hacia el oeste fue un hito histórico, representado como una hazaña individual y colectiva de sujetos que labraron sus sueños y oportunidades en los vastos territorios del Far West. La migración fue clave en el crecimiento de Norteamérica que mediante las políticas de colonización, ratificaron el relato moderno del progreso de la nación. Narración no desconocida en los grupos de poder en la Patagonia que pareció coincidir tanto en el discurso y en la práctica, con los anhelos de instalar ese progreso en la zona. Propagar la "civilización" fue el ideario norteamericano en la convicción que el gran oeste, constituía un espacio de bonanza a quien estuviera dispuesto a luchar por conseguirla. Pensar en el desierto activó un sinfín de juicios que la definen pero también, indica una referencia donde se construyó la imagen de un sujeto diferenciado (el pionero), tempranamente analizado por los intelectuales de la época.

Frederick Jackson Turner (1861-1932) historiador norteamericano, reconoció en la constitución del pionero características como la autonomía, la individualidad y la robustez que permitió retroceder la barbarie en los terrenos recién conquistados; asimismo, afirmó que la convivencia directa con la naturaleza silvestre distanció este sujeto del carácter europeo. En su obra The Frontier in American History (1893), sistematizó la relación entre la conservación del wilderness (vida natural/salvaje) y la constitución de la identidad nacional a partir de interpretación de la frontera, y el papel fundacional del sujeto norteamericano. Por lo tanto, habitar la frontera engloba dos procesos: la marcación de los límites (barbarie/civilización) y propagar la colonización conforme el ideario de estado moderno:

Turner desarrolló dos tesis complementarias para explicar la condición fundacional para la conquista del oeste para la nación norteamericana: una, referida a la frontera y otra, a la excepcionalidad de su pueblo [...] una forma de interpretar la conquista del oeste y una manera de separar a los norteamericanos de sus orígenes europeos, para reforzar la idea del surgimiento de una nueva nación (Fortunato, 2005:325).

Rápidamente, la planificación socioeconómica de EEUU derivó hacia una urbanización de estructura semi-industrial e industrial que aumentó el número de habitantes. Éxito que no pudo apañar las voces disidentes que observaban la destrucción temprana de los paisajes, producto de la acción de la agricultura y la industrialización sin miramientos. El conflicto detuvo la atención de personalidades ligadas a la política y a las ciencias, más próximas a un pensamiento conservacionista, exigentes de una pronta solución a la debacle de la naturaleza. Problema que asentó una serie de cuestiones a responder: qué conservar, quiénes, cómo y por qué mantener algunos terrenos fiscales. Una de las corrientes más influentes fue el transcendentalismo de Ralph Emerson y Henry Thoreau, promotores de la idealización del primitivismo en la convicción que la naturaleza detenta valores positivos, extraviados durante la conquista del oeste por el proyecto de la civilización (Fortunato, 2005:329). Sus principios filosóficos y éticos consideraron a la naturaleza como un templo, donde se depositaban las energías creadoras de Dios. El respeto del equilibrio natural era sustancial para frenar el deseo imparable del materialismo excesivo en las sociedades.

De acuerdo a Diegues, entre fines del siglo XIX y comienzos del XX la discusión acerca del wilderness en EEUU se situaba en dos posiciones: los conservacionistas y los proteccionistas. En el primer caso, el exponente más notorio fue Gilfford Pinchot, político impulsor de la defensa racional de los recursos naturales y participante clave en la institucionalización estatal que, promovió el cuidado y la fiscalización de las reservas de bosques para las futuras generaciones. Pinchot (Jefe del Programa de Bosques Nacionales), concuerda con el presidente Theodore Roosevelt, en defender la naturaleza sin desconocer el desarrollo de las localidades, es decir no de concebir una naturaleza intacta sino amparar su cuidado con el uso sabio de las fuentes naturales. 
El preservacionismo, en cambio, definió la naturaleza mediante parámetros estéticos y espirituales, su fundamento fue buscar espacios para contemplar el wilderness en estado puro, lejos de la intervención humana. George Perkins Marsch en el texto Man and Nature (1864), subrayó las consecuencias negativas para el medio ambiente si la tecnología mantiene una posición central. El texto reconoce el papel positivo del hombre en la transformación del mundo y su cara contrapuesta: un agente devastador en la composición de la tierra. Igualmente el naturalista y explorador John Muir, utilizó su experiencia de viaje por los paisajes americanos, en una práctica de defensa a la vida natural, el respeto a lo salvaje y la preservación de bloques ambientales. Promovió la fundación del grupo conservacionista Sierra Club en 1892, tribuna en que insistió en la relación intrínseca entre naturaleza y los seres humanos, ya que sus esfuerzos iban en la dirección de frenar la concepción de supremacía del hombre y aspirar a recolocarlo en el seno de la naturaleza.

Relevante fue la gestión del presidente estadounidense Theodore Roosevelt, respecto a la conservación y explotación racional de los recursos naturales. Durante su gobierno (19011909), fundó varios parques nacionales en la convicción de replicar el mismo espíritu del Parque Nacional Yellowstone: mantener un espacio de contemplación de la naturaleza para los ciudadanos norteamericanos. Roosevelt sintetizó las dos vertientes más preponderantes en esta época: promulgar un marco legal que protegiera los paisajes de la nación y permitir el desarrollo local con una explotación moderada de sus recursos. La figura de Roosevelt no es desconocida en Chile y Argentina, ya que visitó oficialmente ambos países en 1913. La comitiva del ex presidente recorrió los territorios que posteriormente delimitó los parques nacionales de Nahuel Huapi (Argentina) y Benjamín Vicuña Mackenna (Chile). $\mathrm{Su}$ experiencia política fue seguida por distintos intelectuales latinoamericanos, en la divulgación de desafíos comunes en el tema de la conservación. Específicamente en Argentina, el contacto entre Roosevelt con Francisco Perito Moreno, apuró quizás, la política conservacionista entendida como una fuente de civilización y de reafirmación nacional en relación con los territorios patagónicos:
Al igual que Roosevelt, Moreno consideraba que los recursos naturales se convertían en elementos que otorgaban poder económico y sobre los cuales, a su vez, era posible sustentar la identidad nacional. Moreno propone la organización de una institución que realice estudios de suelo, mensure oficialmente la tierra y regule las acciones de la actividad privada ya que rápidamente esta estaba haciendo un uso inadecuado de los recursos correspondientes a los ámbitos recientemente ocupados por el estado argentino [...] el proyecto conservacionistauso racional de recursos y cuidado de los mismos- para las generaciones futuras explicitamente se convertía en un campo de aproximación entre los politicos e intelectuales entre ambos países; en términos de Roosevelt, el ideario conservacionista se incorporaba al proyecto civilizatorio compartido (Zusman, 2011).

Chile y Argentina coinciden en proteger los recursos naturales con la marcación de áreas protegidas, además de representar turísticamente la Patagonia como el lugar arquetípico de lo inhóspito, mágico, inquietante, etc. Aspectos que una y otra vez refuerzan un proceso interesante de revisitar, teniendo presente los siguientes puntos:

- Argentina emplazó en los terrenos patagónicos la problemática de los parques nacionales, concordantes con la noción de conservación impulsada por EEUU. Chile por su parte, elaboró una estrategia de preservación entre las regiones de los Lagos y la Araucanía. El turismo en la Patagonia irrumpe institucionalmente desde los años 50 del siglo $\mathrm{XX}$; sin embargo, existieron iniciativas locales anteriores a esta fecha que se preocuparon en el aumento de rutas turísticas y en locaciones asequibles para el arribo de los visitantes.

- El sistema turístico en la Patagonia no fue un proceso homogéneo, cada lugar supone circunstancias específicas coparticipantes de un relato mayor, de la trascendencia del turismo en el territorio patagónico.

- El turismo no fue una salida directa a 
la decadencia del modelo agro-exportador. La productividad del turismo creció junto con el incentivo hacia los mercados internacionales, que derivó en un cambio en la estructura del trabajo (la lucha por los derechos y deberes). Además el capitalismo dentro de su ideario, acotó los lugares en dirección de una economía ascendente en el consumo de bienes y servicios.

- Inicialmente el turismo en Chile y Argentina promovía el descanso en la playa y la montaña, el paisaje patagónico se concibió en distintos proyectos pero, adquiere su consolidación internacional después de los años 1940.

- La visibilidad de la Patagonia en el discurso turístico implicó la participación de un sinnúmero de prácticas sociales: emprendimientos locales, obras de ingeniería, una política turística, inversión privada y el apoyo logístico de organizaciones. Entre los actores locales destacan el Touring Club y Automóvil Club, impulsores de rutas turísticas y un desarrollo vial acorde con sus exigencias. Asimismo, las exploraciones científicas y deportivas dan a conocer las diversas vías que en el corto tiempo, obtuvieron gran importancia para el espectáculo de la mirada.

\section{LA REPRESENTATIVIDAD TERRITORIAL Y TURÍSTICA EN LA CONFIGURACIÓN DEL PARQUE NACIONAL NAHUEL HUAPI EN ARGENTINA}

La ocupación territorial consolidó el órgano estatal que controló y definió simbólicamente el espacio y sus habitantes. Cooperaron en este objetivo, la instalación de los parques naciones, en el camino de neutralizar los conflictos limítrofes, asumir un nuevo nicho económico (el turismo) y "vaciar" los espacios en pos de conservar la naturaleza. En general, los estudios coinciden en la persistencia de cierta continuidad del discurso turístico hasta los años 70, correspondiente a la preponderancia del Estado en la administración de una línea turística. Posteriormente, el

2 El proceso de turistificación abarca las prácticas de reconocimientos de un atractivo turístico y las representaciones neoliberalismo impuesto por la dictadura en Chile y las transformaciones progresivas de la estructura económica en Argentina, significó el abandono de un criterio de desarrollo interno por una apertura económica internacional, y el Estado benefactor, quedó rezagado por el criterio de Estado subsidiario. Las consecuencias más evidentes en el mundo del trabajo fueron la inestabilidad laboral, el recorte salarial, la desocupación, etc., que fragmentó y diversificó el sentido del turismo y su acceso:

Un turismo masivo vinculado al mundo del trabajo entra en crisis por varias razones; por una parte, el empobrecimiento excluye a un creciente número de habitantes del país de la posibilidad de practicar turismo; por otra, la crisis de la representación sindical tiene efectos en este tipo de turismo, disminuyendo la cantidad de afiliados que se benefician del mismo [...] la mayor flexibilización laboral incide en la forma en que se tendrá acceso al tiempo libre, dando lugar a una mayor fragmentación del mismo (Bertoncello, 2006:329).

Por otro lado, la turistificación ${ }^{2}$ (Navarro \& Vejsberg, 2009:417) de los lugares, conlleva la objetivación de un destino turístico como valor transable en las diversas agencias de viajes, que junto a una política abierta al mercado, mercantiliza las sociedades (cultura, historia, paisajes, personas, etc.), lo que apura el quiebre de la comunidad local con los paisajes enmarcados en las ofertas turísticas.

La inauguración de la práctica turística y los pasos iniciales del primer parque nacional

Mientras la elite porteña disfrutaba del ocio en Europa cerca del mar o la montaña, sincrónicamente el Estado argentino, procuraba fortalecer los lazos de identificación con el ciudadano, en el cual el nexo geográfico modeló el camino preferencial del ejercicio estatal entre fines del siglo XIX y principios del XX. Apelar a los grupos selectos para optar por los territorios nacionales, necesitó de una valorización de los espacios internos según los siguientes atributos:

que se ejercen sobre él como la generación de una infraestructura o medios de accesos que concretiza su uso. 
habilitar la playa y la montaña en correspondencia a los paisajes europeos (mar del Plata y la Suiza Argentina), formar un "mapa turístico" donde el acceso era fundamental (el tren y luego el automóvil) y contar con un equipamiento adecuado (hoteles y servicios). Así fue que la extensión ferroviaria a Mar del Plata (1886) y la inauguración del hotel Bristol (1888), convirtió a esta ciudad en uno de los destinos paradigmáticos. Más tarde se incorporó las propiedades curativas de la sierra de Córdoba y las termas de la Provincia de Jujuy y el Salta (Bertoncello, 2006:319-320).

Acerca de la prefiguración del Parque Nacional Nahuel Huapi, fue substancial el retorno de los terrenos en posesión de Francisco Perito Moreno al patrimonio estatal en 1904. Superficies adquiridas por sus servicios prestados durante los litigios limítrofes con Chile. La decisión de Moreno de donar tres leguas de las veinticinco que llegó a poseer, era encauzar un proyecto de conservación de la naturaleza en pos de enfatizar la narrativa identitaria vinculante con la geografía. Fue el primero en pensar el diseño del parque en coordinación con la conectividad del tren, el asentamiento de una colonia y los organismos públicos. Moreno conoció la política conservacionista norteamericana respecto a la valoración de los recursos naturales y el fortalecimiento del carácter nacional. Ideario que replicó en el momento de plantear sus ideas en la constitución de los parques en este sentido, el turismo no fue central en la difusión inicial de estas materias. Las actividades en el orden intelectual y social aportaron conceptos respecto a que los parques nacionales, consolidaban el emprendimiento "civilizatorio" en el país. La canonización de determinados paisajes legitimó el papel del Estado, en la posesión territorial, además de buscar una solución neutral en los puntos geográficos conflictivos con Chile (Navarro \& Vejsberg, 2009:414-433).

Afín con este proceso, la inauguración en Mar del Plata del Museo de Historia Natural (1844), favoreció la enseñanza del sentimiento patriótico mediante la síntesis evolutiva de su formación, con la contemplación sin escándalo, de la colección de "restos" indígenas como un relato naturalmente anterior a la instauración del Estado:

\section{Para Moreno no sólo el paisaje}

contemporáneo, sino también la fauna, la flora y el hombre "primitivo" constituian las bases sobre las cuales fundar el patriotismo de la joven nación. Este proyecto pedagógico, finalizado a formar ciudadanos, preveía excursiones del alumnado (y de grupos de boy-scouts creados por Moreno...) a parques, museos y escenarios de acontecimientos históricos (Scarzanella, 2002:7).

\section{Anexar naturaleza y la ciudad industrial}

El continuador de los planes de Moreno fue el ingeniero Bailey Willis con el proyecto del Parque Nacional del Sur. En su trabajo, concibió la naturaleza en función a los criterios conservacionista de EEUU: encuadrar un área de la cordillera a la explotación turística (valoración estética) y organizar en las cercanías del parque una ciudad agroindustrial. El entorno sociopolítico no permitió la puesta en práctica de los planes del Ministro Ezequiel Ramos Mexía, en la Comisión del Paralelo 41, encabezado por Willis. Las presiones presupuestarias, internas (el poder oligárquico) y externas (capitales extranjeros), truncaron la implementación territorial en la zona entre los años 1911 y 1914. A grandes rasgos, el boceto del parque regulaba las capacidades productivas del suelo, con la expropiación de los sectores más accesibles y con mayor capacidad agrícola o ganadera, conservaba intacto las reservas fiscales (el parque) e insinuaba el anhelo de un parque adyacente en Chile. Willis se compenetró con el debate de cómo relacionar nación y territorio, por eso el derecho de recorrer los entornos nacionales era para todos los ciudadanos (no únicamente el visitante "culto" de Moreno), llamado que se concretiza sólo hasta el gobierno de Perón a mitad del siglo XX, frente a la impronta del turismo de masas (Navarro \& Vejsberg, 2009: 422).

Los gobiernos conservadores y el turismo de élite. El papel de la DNP en el diseño del Parque Nacional de Nahuel Huapi

Uno de los personajes destacados en los gobiernos conservadores fue Exequiel Bustillo, 
director de la Dirección Nacional de Parques entre los años 1934 y 1944. Durante su gestión, logró congregar un sinfín de asuntos vinculantes a la definición de la naturaleza y el crecimiento de Argentina, tarea que posibilitó la relación entre sociedad y ocupación territorial. Lo particular de la visión de Bustillo fue que complementó las ideas de EEUU (preservación de la naturaleza y control de la explotación), con la perspectiva europea de seleccionar determinados paisajes para la protección fiscal. Pero su estrategia dio un paso más allá -ser un agente territorial-, ya que su labor en la DNP, reposicionó el debate territorial de transformar los terrenos fronterizos en centros urbanos, en el camino de consolidar la soberanía. Así, la conducción del ahora Parque Nahuel Huapi (1934), constituyó un espacio de mediación para introducir el turismo y lo más importante para la Dirección, argentinizar algunas áreas mal integradas en el sistema estatal, ante el peligro latente de los deseos expansionistas del Estado chileno. La operatividad de dichas tareas, significó ejercer el poder en una modalidad centralista, que durante este periodo tensionó la autonomía de las provincias sin reconocer el camino previo impulsado por los agentes locales, entre ellos, los esfuerzos de Emilio Frey (Director Provisional del Parque Nacional del Sud en 1922) de buscar en el turismo, una salida a la crisis de la actividad agrícola en la región:

En las políticas hacia el Parque Nacional del Sur, la intervención conservadora resultaría decisiva: reinstalados en el poder muchos de los desplazados en 1916 -Exequiel Bustillo-, por ejemplo, estaba ligado por lazos tanto políticos $e$ ideológicos, como familiares con Ezequiel Ramos Mexía-; se formularía una política más orientada a la nacionalización territorial que a la protección de la naturaleza, y en ese contexto no sólo se avasallaría la autonomía municipal de Bariloche sino que se impondría un nuevo nombre para el parque -en adelante, Nahuel Huapi-, un estilo arquitectónico europeizante, una política turística elitista y hasta un relato histórico que relegaría al olvido tanto las ideas originales de Moreno y Willis como el largo camino recorrido por los habitantes de Bariloche en pos de un proyecto de desarrollo local que finalmente se tornaría en monoproducción (Navarro \& Vejsberg, 2009: 429).

Para Bustillo, no había sido suficiente la conquista de la Patagonia por el General Roca en la Campaña del Desierto (1878-1879), pues debía completarsela con una representatividad concreta del orden estatal. Entonces, sin abandonar el paradigma de conservación, Bustillo guía sus decisiones hacia una reapropiación del espacio nacional a través, de una apreciación de los recursos naturales en función de su potencial turístico, sobre todo en un momento difícil en la coyuntura internacional que repercutía en la economía regional:

El proyecto de Bustillo tenía dos objetivos principales: de un lado, el desarrollo económico de las zonas comprendidas en los parques, desde la perspectiva de su contribución a la riqueza de la nación $y$, del otro, su integración simbólica y material al territorio nacional. Se buscaba la patrimonialización de esos paisajes convertidos en simbolo de la nación aún para aquellos que no tenían posibilidades de visitarlos. A la vez, y sobre todo en el Parque Nahuel Huapi se procuraba una colonización de un área considerada "vacía" (y por lo tanto, a la vez desaprovechada y peligrosamente vacante) y una argentinización de su población (Piglia, 2007).

Con otras palabras, la organización turística del DNP, cooperó en la efectiva posesión territorial porque confeccionó un inventario de los futuros atractivos en la Patagonia, con la difusión (casi al mismo tiempo), de registros fotográficos y fílmicos. Acciones en vía de formular una economía local diferenciada que perjudicó la distribución de las comunidades locales así como, los modos de significar o relacionarse con el paisaje. En tal sentido, la cimentación general de San Carlos Bariloche según el patrón estético europeo, reiteró el camino elegido por Bustillo de implementar un turismo selecto, marginando a sus habitantes de aquellos entornos naturales. El boceto de la ciudad no fue la única intervención del DNP, la oferta de los deportes de inviernos concordaron con un 
panorama reconocido por los visitantes: un mundo de vacaciones en el cual Sestriere o Davos o Aspen se podían confundir con Bariloche (Scarzanella, 2002:13). Similitud palpable en la integración de especies ajenas a estos entornos (alce, salmones y truchas, etc.), recreando antiguas cacerías aristócratas. Por lo tanto, durante la administración de Exequiel Bustillo, la preservación de la naturaleza no constituye un núcleo esencial en la toma de decisiones, sino que fue una política territorial nacional que planteó las directrices en el orden de determinar qué terrenos conservar, quiénes son sus legítimos propietarios (la alta sociedad porteña y terratenientes), a quiénes desplazar (los indígenas y chilenos), cuál será la fachada urbanística (estilo europeo) y quiénes visitarán el parque (la elite).

\section{La sindicalización en la representación} del turismo

Un cambio radical respecto a la política turística aconteció durante el gobierno de Juan DomingoPerón(1946-1953), conlaAdministración General de Parques Nacionales (AGP). Organismo que sin perder su carácter centralista, modificó la visión en torno a quiénes tienen derecho a la práctica turística con la modificación de actores del mundo laboral y la inauguración del turismo social. La Fundación Eva Perón y los distintos sindicatos, organizaron los días de descanso del proletariado en la visión que, la actividad turística era un derecho ganado por los trabajadores. La redistribución de tal práctica social, necesitó de la instalación de una infraestructura hotelera, transportes y servicios en función a un número creciente de familias, que durante este periodo gozaron de las reivindicaciones proclamadas por el gobierno de Perón. El turismo ingresó a un marco de sentido diferente a partir de la apropiación del slogan de los conservacionistas: conocer la patria es un deber. La frase motivó a la clase trabajadora para disfrutar los espacios vetados antes para ellos. El turismo fue una estrategia que medió en la intensión del Estado, de movilizar las conciencias de sus ciudadanos para valorizar los paisajes emblemáticos del país (pedagogizar el sentido patriótico).

A nivel mundial, el fenómeno del turismo masivo consolidó sus patrones más identificables gracias a las reformas laborales, regulando el tiempo de los trabajadores (ocupación/descanso). En este contexto, las vacaciones constituyeron un derecho y una necesidad y dejó de pensarse en un lujo para pocos. En este terreno, el turismo aceleró una gama de actividades económicas que suscitó la masificación de los paquetes turísticos, caracterizados como económicos, regulados y homogéneos. El gobierno de Perón, utilizó este modelo de consumo y logró el desplazamiento masivo de sujetos, por medio del incentivo económico en los niveles de servicios, hospedajes y transportes. En la praxis, se instaló una noción de temporalidad normada del ocio y la visita en lugares específicos por ejemplo, la gran concurrencia de personas a los balnearios. El Peronismo controló los costos de acceso a las ciudades tradicionalmente visitadas por los grupos acomodados (Mar del Plata y Córdoba). Políticamente, estas medidas significaron una conquista del trabajador y la propagación por parte del turismo sindical del concepto de belleza a los paisajes del país:

El turismo se fue convirtiendo en un componente cada vez más importante de una sociedad que estaba consolidándose como una sociedad de consumo; al igual que sucede con otros bienes y servicios, su demanda es incentivada por los agentes económicos involucrados en la actividad, a través del establecimiento de las habituales relaciones entre consumo, estatus y distinción social (Bertoncello, 2006: 322).

No obstante, el turismo nacional no fue la única gestión de la política turística peronista el comienzo de la internacionalización de los paisajes argentinos sin duda era una posibilidad económica a tomar atención. El emplazamiento de agencias de viajes en el extranjero, fortaleció la difusión de los atractivos de América del sur, especialmente los entornos donde practicar la pesca, el sky, tomar el sol, etc. Trascendente fue la construcción del complejo de Ezeiza (1949), un hito en Argentina por la apertura del país hacia el mundo.

De acuerdo a Claudia Troncoso y Carla Louis, las acciones del Estado en la difusión de los paisajes nacionales, presenta estrategias de apelación concordante con el deseo de establecer 
una mirada turística donde vinculan naturaleza, trabajo y la proyección futura del país. Sus esfuerzos iban en la dirección de sorprender al espectador de las particularidades de cada provincia del país, para equilibrar los atractivos turísticos dentro de los folletos de propaganda turística:

En la Argentina, una de las formas de canonización de los paisajes emblemáticos de la supuesta diversidad natural y cultural del país puede leerse entrelíneas en las políticas de manejo y gestión de la Administración General de Parques Nacionales y Turismo. Utilizando diferentes recursos y apelando a diversos registros, durante la gestión peronista se interpeló a un sujeto "turista": se buscó seducirlo con los paisajes para el disfrute de su tiempo libre y se pretendió también generarle el compromiso moral y patriótico de conocer la "diversidad geográfica" del país. Porque, pese a que ciertas frases explícitas y las secciones bilingües de la obra sugieren que entre los destinatarios imaginados se esperan lectores extranjeros, no puede negarse que también se esperan lectores locales que aprecien la potencialidad turística del país que la gestión peronista busca desarrollar (Louis \& Troncoso, 2005:189).

\section{¿PRESERVAR O RACIONALIZAR? EL DEBATE ECONÓMICO Y CONSERVACIONISTA EN LA FORMACIÓN DE LOS PARQUES NACIONALES EN CHILE}

El trabajo de especialistas científicos contratados por las nacientes repúblicas, dan cuenta de la preocupación por obtener una descripción general de las ventajas territoriales y la proyección productiva de los recursos naturales. A mitad del siglo XIX, la alteración geográfica producto de la excesiva explotación del suelo, era la evidencia concreta del agotamiento real de los recursos naturales, momento para pensar las estrategias que detengan la degradación total de la naturaleza. De esta manera, Chile ingresa en el debate de la conservación y uso racional del espacio en sintonía con los demás países latinoamericanos.
El botánico y naturalista Claudio Gay, a mitad del siglo XIX, fue uno de los primeros en denunciar a las autoridades los grados de desertificación en los montes, generado por la tala indiscriminada de los árboles. Acusa a la minería de la baja sostenible del bosque y realiza un llamado urgente, de aprobar una normativa que regule los privilegios de una área productiva en desmedro de otras (la agricultura). Gay investigó el capital natural del país, labor que lo llevó a recorrer diversos parajes en el cual, presenció los bruscos cambios en el entorno particularmente, visitó la provincia de Coquimbo y dio cuenta de la baja sustantiva de la vegetación autóctona. Indicó como responsable las minerías del cobre, demandantes de gran cantidad de leña para la fundición del metal.

Sus conclusiones fueron publicadas en 1838 en El Araucano (dirigido al Ministerio de Interior), remarcando sus observaciones (experiencia empírica), las causas y las soluciones que de alguna forma, unirían en su discurso tanto la tarea científica como la decisión legal-política. Según Gay, la aridez no era una característica propia del lugar sino producto de la intervención del hombre y que las ordenanzas municipales no restringen las explotaciones mineras, restándose de una mirada global de los efectos adverso a la naturaleza. Sugiere las siguientes propuestas: primero, regular la actividad minera y responder a la demanda de leña con la introducción de árboles de rápido crecimiento como el sauce y el álamo, especies atrayentes de electricidad y de una gran belleza estética. Segundo, fomentar la minería en otras provincias aumentaría el caudal de los bosques y la recuperación de terrenos fértiles para la agricultura, además de diversificar el trabajo en las regiones.

Gay no esconde en su discurso su preferencia por el área agrícola -partícipe de las ideas de un grupo de élite-, simpatizante del optimismo ilustrado europeo del siglo XIX, creyente del enciclopedismo y en la razón científica como motor del progreso de las naciones. Por lo tanto, Gay define la conservación de la naturaleza de acuerdo el uso útil dentro de un sistema productivo (bajo un método racional), y que las leyes deben recoger las conclusiones científicas en sus distintos ámbitos. La primacía de ciertas áreas productivas, limitó en este periodo, la puesta en marcha de 
varios decretos desde 1859 que intentaban normar la explotación de los bosques y la poca urgencia de los organismos estatales, de definir los bienes naturales frente el desafío de conservar en pos del crecimiento del país.

Los argumentos conservacionistas adquieren un nuevo cariz con el naturalista Federico Albert (fines del XIX), considerado precursor de la institucionalidad estatal en el manejo de los bosques, suelos y el agua, pues define una organización general de qué entender por recursos naturales y cómo utilizarlos dentro de un sistema productivo que acude a la naturaleza para su sostén. Albert se desempeñaba en el Museo de Historia Natural (1889-1898), preparando los esqueletos e inventariando las especies naturales del país, colaborador cercano de Rudulfo A. Philippi. En 1898, asume el desafío dentro del Ministerio de Industria, de estar a cargo de los estudios de zoología y botánica, y en tal contexto, la investigación de climatización de especies foráneas en relación a los avances de las arenas volantes, causantes de los estragos en la agricultura del Norte Chico. El botánico observó que si existiera un muro vegetal (el bosque), se contendría el aumento de las dunas. Albert publicó una gama significativa de trabajos de divulgación científica y proyectos de reglamentación respecto el tema de la conservación, y el manejo de los recursos naturales. Formó un equipo de colaboradores cuyas tareas, iban en el camino de retroceder la desertificación de las laderas y desplegar en el país, un tratamiento de crecimiento y tala de los bosques y el empleo racional de los suelos.

En sus viajes por Europa, tomó contacto con otros profesionales del área, que coincidían en la importancia de una ciencia forestal armónica en la conservación y la explotación, sin destruir la capacidad regeneradora de la naturaleza. En 1911 formó la Inspección General de agua, bosques, pesca y caza -Albert fue su director-, herramienta institucional desde el cual presentó un proyecto de ley dirigido al Congreso durante la presidencia de Ramón Barros Luco, con una batería de artículos que demarcaban los terrenos forestales de propiedad fiscal y las medidas de conservación, fomento y gestión:

El proyecto tenía un carácter fuertemente conservacionista en el que incluía la definición de lo forestal, además de lo que se declarase al efecto, todo aquello relacionado con la protección física de las obras públicas, las que contribuyesen a la calidad y mantenimiento del caudal de aguas, los situados en cuencas hidrográficas, los que cumplieran un papel protector con relación a la erosión, inundaciones, avance de dunas y aquellos relacionados con el mantenimiento de determinadas formas de vida económica de los pueblos y los que presentasen valores en su flora o fauna que conviniera conservar (Camus, 2008:59).

Sin embargo, esta iniciativa discutida técnicamente por especialistas en el área, se enfrentó a la indiferencia de legislar por los temores de perjudicar la minería y la agricultura. Sólo verá sus frutos en los decretos $\mathrm{N}^{\circ} 656$ de 1925, $\mathrm{N}^{\circ}$ 265 de 1931 y la ley vigente de bosques de 1931, Decreto Supremo N 4363 del 30 de junio.

A grandes rasgos, el pensamiento de Federico Albert apuntó a seleccionar entre los terrenos aptos /no aptos para la agricultura, destinar los cerros a la reserva de bosque que provea de madera (combustible) y evitar la desertificación como el control del caudal de los ríos, ya que la naturaleza se comporta con un efecto dominó. Para Albert, el Estado debe empoderarse en el tema de la conservación, con reglas claras en la forma de organizar el espacio. En este sentido, tanto Albert como Gay, no conciben una naturaleza intocable, sino que les preocupa su efectiva empleabilidad, ámbito donde la ciencia fue fundamental en el análisis estadístico del espacio y el diseño de una política forestal en el país.

Tras retirarse por motivo de salud, asumió el cargo su más cercano asistente Ernesto Maldonado, quien logró establecer una tradición forestal en Chile, encaminado en el deber de concentrar los beneficios sociales y ambientales dentro de las tareas de conservación de los espacios naturales: objetivo más o menos intacto hasta los años 70'. La irrupción dictatorial del General Pinochet, inauguró una política neoliberal que desmiembra el sector público forestal, limitando las funciones centrales de las instituciones, las vacía de contenido y subraya el carácter sólo productivo en torno a la naturaleza. Las consecuencias fueron 
la destrucción de los bosques nativos y junto con ello, los modos de vida (cultural y animal) en torno a los bosques, expulsión de las comunidades rurales (especialmente los mapuche), para entregar terrenos a los grupos terratenientes e inversiones privadas, y disminuir la biodiversidad (cambiar paisajes y prácticas agrícolas), entre otros (Casals, 1999).

Los movimientos de la política forestal y sus nexos con la conservación de la naturaleza

La irrupción del concepto de áreas protegidas en la zona de Villarrica, recoge en la praxis la discusión anterior: crear reservas forestales para controlar óptimamente el cuidado y explotación de los bosques es decir, los primeros parques nacionales emergen de las reservas forestales como el Parque Benjamín Vicuña Mackenna de la Reserva Forestal Villarrica (1925) y Vicente Pérez Rosales de la Reserva Llanquihue (1926).

El Decreto Supremo No 1722 del Gobierno de Barros Luco, consigna la Reserva Forestal Villarrica en 1912 con 265.625 hectáreas. El Parque Benjamín Vicuña era un espacio de protección de las bellezas naturales vinculada hacia el fomento del turismo, siempre y cuando no interrumpiera el trabajo agrícola y los planes de colonización en el sur. El parque alcanzó las 71600 hectáreas en el gobierno de Arturo Alessandri con la firma del Decreto Ley $\mathrm{N}^{\circ} 3789$ el 21 de julio de 1925:

Considerando que es conveniente fomentar el turismo ya que con ello se obtiene ventajas de importancia y se dá a conocer el país al extranjero; que para este objeto es necesario tomar medidas que eviten el agotamiento y destrucción de las bellezas naturales, a objeto de que atraigan a los viajeros; que debe tragarse de que los terrenos que se destinen a este objeto reúnan las condiciones de belleza necesaria y al mismo tiempo que no tengan un gran valor como aprovechamiento agrícola, pues de otra manera resultaría poco económico la creación de Parques de Turismo; que no se sustrae para los efectos de la colonización ninguna superficie útil para la atención de los compromisos que el Gobierno tiene de radicación de colonos, en los terrenos que se van utilizar.

La justificación principal en la formación del parque fue el desarrollo del turismo, en la que se propuso: las posibles rutas para alcanzar las vistas más bellas del lugar como el volcán Villarrica y los lagos Colico y Caburga. No obstante, en 1929 el Decreto N³654, modificó nuevamente los límites de la reserva forestal y el parque, unificando ambos espacios pero, conservando el nombre de la Reserva Forestal Villarrica (se excluyó unas 90.000 hectáreas para la colonización). El Decreto, buscaba tanto resolver el problema político de los expatriados de Argentina como alejar a los recientes colonos que se apropiaban de los suelos destinados a la reserva forestal ante la falta de tierra.

En los decenios siguientes, aumentó el acuerdo entre las autoridades para incrementar la formación de espacios naturales protegidos relacionados con la actividad turística: preservar y fomentar las bellezas naturales [...] que determinan una gran atracción turística (Decreto $\mathrm{N}^{\circ}$ 2236, del 28 de julio de 1940) (Cabezas, 1988:51). En 1940, se creó el Parque Nacional Villarrica dentro de una situación más favorable para el incentivo turístico, porque la ciudad había aumentado su número de habitantes y la comunicación ferroviaria disminuía los tiempos de viaje y ofrecía mayor seguridad a sus visitantes. Los límites del nuevo parque no coinciden con el desafectado en 1929, aunque sí comparte algunos terrenos colindantes de la Reserva Forestal Villarrica. Sus mayores atractivos eran los volcanes de Villarrica, Quetrupillán y Lanin que ofrecían hermosas postales a sus visitantes. En Chile, a lo largo de un siglo, las reservas forestales o los parques nacionales van mutando sus límites o se desligan sus terrenos, principalmente por las modificaciones en la política forestal, la colonización o los anhelos de los privados de apoderarse de los territorios más productivos.

\section{REPRESENTACIONES Y PRÁCTICAS SOCIALES EN LA TRASLACIÓN SIMBÓLICA DEL PAISAJE}

Con el arribo de la política pública en 
la tarea de diseñar los parques nacionales, sobresale el inventario de bellezas naturales, adjuntas en los espacios declarados conflictivos históricamente. Uno de ellos fue el sector de la Araucanía como territorio bélico, no civilizado. Sin duda, el turismo incidió en transformar la belicosidad en las regiones de Arauco, Valdivia, Osorno, Llanquihue y sus proximidades, a través de un proceso articulado de registros (discursivos $y$ visuales), que mencionaban una y otra vez la fascinación por la naturaleza, diluyendo la tensión socio-política (aún no resuelta) y así, concentrarse en el detalle estético que la mirada militar, científica y de los colonos no revelaron especialmente en sus testimonios:

la mayor parte de los testimonios sobre la zona se refirieron al territorio mapuche y a la región de Valdivia y Llanquihue como un vasto espacio todavía no integrado cabalmente al devenir histórico de la república y en amplios sectores todavía en disputa en Argentina. En ese contexto, la construcción de las miradas sobre el sur de Chile había estado a cargo de militares, industriales $y$ exploradores. Los primeros describieron el proceso de ocupación militar de la Araucanía iniciada en la década de 1860; por su parte los colonos dieron cuenta de la ocupación productiva [...] los científicos, finalmente, estuvieron a cargo de describir de modo objetivo el nuevo territorio, dimensionando sus limites y levantando la geografía que se incorporaba a la nación. Estas miradas complementarias sobre el territorio consolidaron una imagen del sur de Chile en el que se resaltaban la condición de frontera indómita que resumía una percepción centenaria que sólo vendría a ser modificada tras la irrupción del turismo (Booth, 2010:14).

Según Rodrigo Booth, la consolidación de la Suiza chilena fue producto de un sinnúmero de antecedentes escritos y visuales que recalifican el carácter indómito de la selva araucana, notorio hasta gran parte del XIX. La irrupción del turismo en las regiones mencionadas, orientó en un corto tiempo, el asentamiento de un nuevo canon estético: el sur es bello. El paisaje del sur se adjetivó de civilizado de acuerdo a su semejanza con el europeo, aunque la extensión ferroviaria (1910) también colaboró en la construcción de sentidos, porque los servicios ofrecidos domesticaron el espacio en la evidencia concreta del control estatal. Además de los avances técnicos, una cantidad de publicaciones promovían los rumbos turísticos más sobresalientes de conocer, y retratar fotográficamente la reincidencia de tales prácticas, presentó un lugar accesible y seguro que logró el consenso representativo de pensar el sur de Chile como un lugar tranquilo y hermoso, de personas afables y hospitalarias:

A través de la publicación de imágenes de algunos lagos pre-andinos, volcanes $y$ bosques, pero también nuevos pueblos turísticos e infraestructura hotelera recién construidas, la empresa de los ferrocarriles contribuyó a dejar atrás las referencias a la mítica "selva araucana" para presentar un sur accesible $y$ domesticado. Lejos de la estampa riesgosa de antaño, el ferrocarril había permitido que el turista llegara cómodamente hasta el lugar donde podría aprovechar un tiempo de ocio que paulatinamente se había democratizado en la sociedad chilena (Booth, 2010:23). El ejemplo anterior, nos parece interesante para observar en la región patagónica los alcances del turismo en la construcción representativa del Parque Nacional Torres del Paine puesto que, en los últimos decenios, su imagen se ha fortalecido internacionalmente, en cuanto sintetiza el estereotipo del paisaje patagónico que mira el resto del mundo. Sobre todo porque en el momento de preguntar qué se entiende por la Patagonia, mayoritariamente en el imaginario turístico acuden a la imagen de los macizos del Paine, un entorno natural que convoca a la aventura en un lugar solitario, lejano y bello. Categorías buscados por los turistas que cada año, aumentan su número ${ }^{3}$ gracias a la gestión de diversos dispositivos, agencias de turismo, políticas públicas, revistas de viajes, etc., que representan y apelan constantemente a un tipo de viajero (mochilero, jóvenes y con rasgos occidentales), a vivir una experiencia sin 
precedente en el "fin del mundo". Entonces, si la Patagonia chilena era un territorio ligado principalmente a la actividad ganadera, cuyo tesón de los inmigrantes chilenos y extranjeros fundaron ciudades vinculantes con la economía emergente, qué circunstancias recalificaron la geografía dentro de la tribuna turística, palpable en la coordinación de servicios, rutas y vistas que invitan a ciertos sujetos a explorar y fotografiar (se) en los paisajes seleccionados.

\section{La primera exploración turística en la zona del Paine}

Entre 1877-1896, los desplazamientos por el sur patagónico fueron de reconocimiento general de la geografía interna, recopilación informativa en un contexto de litigios fronterizos con Argentina o bien, investigaciones sobre el sostén territorial (relieve hidrográfico, montañoso o los suelos). No obstante en 1879, un grupo de aristócratas ingleses arribaron a Punta Arenas. La motivación del viaje era disfrutar la experiencia de vivir entre los parajes solitarios de la Patagonia, practicar la caza y descansar espiritualmente fuera de las comodidades de sus mansiones. El diario de viaje de Florence Dixie (la única mujer), recogió las apreciaciones y el detalle del itinerario entre Punta Arenas y la tierra de los baguales (la zona del Paine). La discrepancia de propósito con los viajes exploratorios, posicionó el periplo inglés como el primer antecedente de un viaje turístico en el área aledaña a los macizos del Paine, donde el placer y el disfrute del ocio fue el eje movilizador de esta particular comitiva: ¿Cuál era la atracción de ir a un lugar tan apartado y a tantas millas de distancia? La respuesta estaba implícita en sus propias palabras [...]. Lo escogí precisamente porque era un lugar exótico y lejano [...] Hastiada momentáneamente con la civilización y su entorno quería escapar a algún lugar donde pudiera estar más alejada de ella como fuera posible (Dixie, 1996:18).

Florence Dixie organizó el relato de modo

3 El Parque Nacional Torres del Paine a nivel estadístico es una de las áreas protegidas de Chile que más ha aumentado el número de visitas. El año 1985 el número total de visitantes fue cronológico, muy pendiente en el ejercicio de la cacería de distintas especies a medida que avanzaban hacia los espacios interiores. La explicación del desarrollo de la caza abarcaba la técnica en el abordaje del animal o ave, las dificultades de atraparlas y la recompensa de un exquisito plato. Por lo general, las agotadoras jornadas a caballos fueron los mayores obstáculos del viaje; la carestía de alimentos o el mal tiempo, no parecía romper el entusiasmo sino que fue un componente más en una aventura de tal magnitud:

Recuerdo una infinidad de emocionantes cacerías y muchas noches agradables alrededor del ameno fuego del campamento. También recuerdo muchas incomodidades -el terremoto, la lluvia que nos empapaba, el bochornoso sol, los despiadados mosquitos y los terriblemente demoledores vientos-. Pero con el placer que miro hacia atrás mi vida silvestre en la Patagonia, poco pueden disminuir estos desagradables recuerdos. Pero en conjunto, contando todo, fue un tiempo muy feliz y un tiempo que volvería alegremente a pasar (Dixie, 1996:252).

Julius Beerbohm era el único que conocía anteriormente la Patagonia -acompañó a un grupo de cazadores en 1877 en el tramo de bahía Blanca-, principal motivador de la comitiva inglesa de la existencia de un lugar maravilloso en la zona andina visitado sólo por los baqueanos (el valle de los baguales, llamado después el Paine). La aventura tenía un destino predefinido, un espacio que rompería con la monotonía de la pampa desértica; por lo mismo, avistar la abundante vegetación, sumada a la sensación de un clima más templado y el conjunto de montañas, sobrecoge de tal manera, que en el texto se traduce en una descripción visual y escrita colmada de magnificencia:

Nos apuramos ansiosos de alcanzar la entrada al cañadón y avistar lo antes posible la tierra prometida [...] delante nuestro se extendía una pintoresca

de 6850 personas, con el 36\% de extranjeros. En el año 2013, el cálculo de visitantes fue de 143253 personas, cerca del 61\% la componen extranjeros (Corporación Nacional Forestal). 
llanura cubierta de suave pasto verde y salpicada por aquí y por allá de grupos de hayas, atravesados en todas direcciones por murmurantes arroyos. El fondo estaba conformado por cerros boscosos, detrás de las cuales se encumbraba nuevamente la cordillera. Tres altos picos de tinte rojizo y de la misma forma que la aguja de Cleopatra, constituían un aspecto sobresaliente en el paisaje [...] cabalgamos contentos hacia los cerros pasando muchos rincones hermosos $y$ disfrutando una fascinante vista del paisaje doblemente encantado después de la fealdad de las planicies (Dixie, 1996:167-168).

El relato anterior, seleccionó los límites de un entorno digno de mirar, una naturaleza de ensoñación abundante de vegetación, frutos enormes, animales mansos y la espectacularidad de las vistas que construyen una postal fascinante, tarea en que colaboraron sin duda las ilustraciones de Julius. Observamos que en el proceso de representación del Paine como un lugar espectacular, estas narraciones preceden a las significaciones que replican la práctica turística en todos sus ámbitos. La insinuación de un horizonte desde donde observar el área del Paine, aumentó el sentido de grandiosidad de su superficie, si se incluye además, el retrato del elemento humano en los rincones de un paisaje valorado como único y extraordinario. Recurso utilizado por las publicaciones actuales en la promoción de una experiencia sin paragón en la Patagonia.

\section{El potencial paisajístico del sur patagónico según Alberto de Agostini}

La obra de Alberto de Agostini fue de gran trascendencia en la documentación de una realidad patagónica, en un periodo de transformaciones sociales como el triunfo de la ganadería y el desbarajuste de la cultura indígena. Gran conocedor de las cumbres patagónicas en su afición por el montañismo, recorrió extensas y heterogéneas geografías; sin embargo, Agostini en sus escritos no sólo explica el relevamiento territorial sino que avanzó un paso más allá: proponer una lectura del potencial turístico en la región concordante con el trabajo incipiente de los agentes locales (por ejemplo, el Touring Club).

El sector del Paine lo recorrió en varias ocasiones, variando sus objetivos y funciones: explorar la geografía (1917), ascensión de montañas (1931), avistamientos aéreos (1937) y patrocinador de expediciones andinas (1957). En 1946 publicó la Guía turística de Magallanes y Canales Fueguinos (De Agostini, 1946), texto en que Agostini cooperó con el movimiento turístico aún rudimentario en la organización discursiva y visual de los principales atractivos de la región.

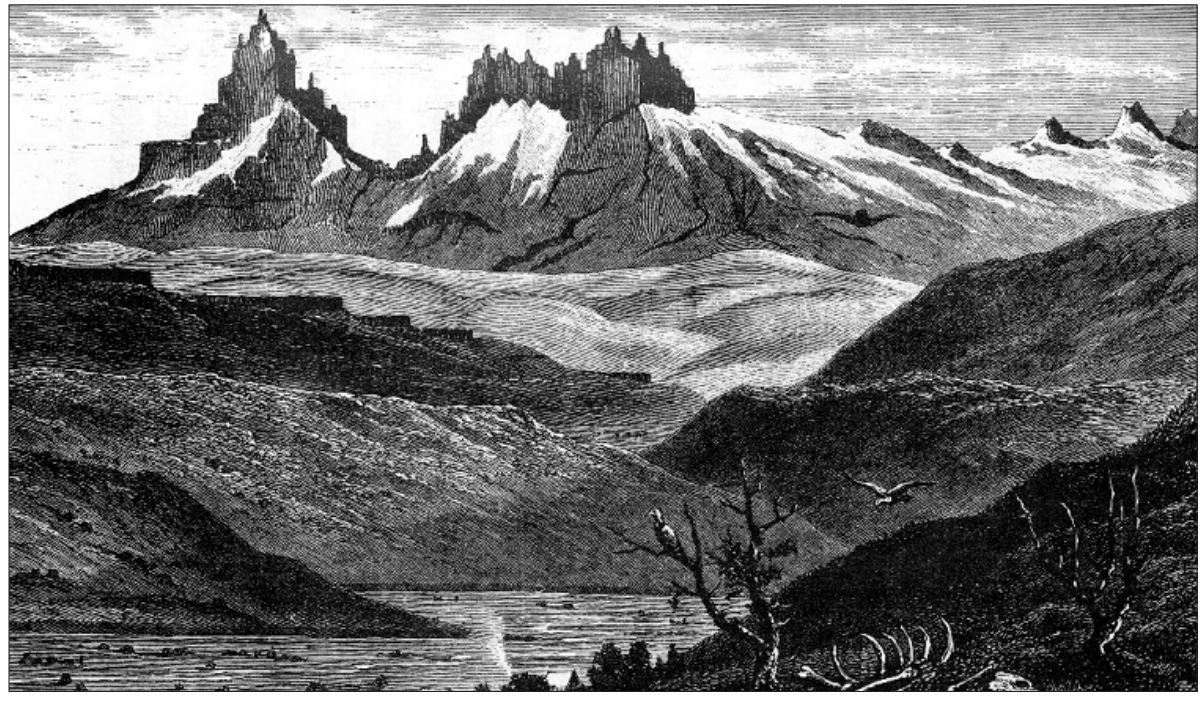

Fig.1. El valle de los baguales, por Julius Beerbohm (Dixie, 1996:181). 
Los once capítulos describieron hitos regionales (la historia colonial española, el descubrimiento del estrecho y el asentamiento estatal en el siglo XIX) y la labor eclesiástica visible en las construcciones como el cuidado de los indígenas (las misiones). En el capítulo V "Turismo en Magallanes", delineó las vías de acceso a los atractivos paisajísticos, en el afán de responder al futuro visitante y las inquietudes iniciales de un mercado turístico emergente (dónde y cómo). El primer destino fue la ciudad de Punta Arenas y sus alrededores, divididos entre el avistamiento de lugares históricos (fuerte Bulnes), los espacios distintivos de la economía regional (mina Loreto, las estancias y frigoríficos) y el disfrute del ocio (practicar el sky). En la provincia de Última Esperanza, se detuvo en la ciudad de Puerto Natales (la ciudad más cercana al Paine) con la mención de los hoteles existentes e indicando la calidad de los caminos hacia la cueva del Milodón y Torres del Paine.

Las especificaciones de Agostini, precedieron a la política estatal de mirar el sur patagónico dentro de las lógicas del mercado turístico. A modo de folleto, describió las bellezas naturales y evaluó la calidad de los servicios habilitados para acoger a sus visitantes (comodidad, seguridad y acceso), elementos básicos en la construcción de un destino turístico. Los problemas no son ignorados por Agostini, pero mantuvo en el núcleo del texto, el anhelo de promover la hermosura del paisaje. De alguna manera, en esta guía motivó la formación de vistas del entorno patagónico, en otras palabras, la inscripción textual y visual estableció una manera de mirar la heterogeneidad de los espacios como capas ascendentes, que finalizó con el dominio de las cadenas montañosas. Registro visual que se replica todavía en cada guía turística o testimonio escrito y fotográfico de sus visitantes:

Los dos macizos del Paine y del Balmaceda con sus atrevidos e imponentes cumbres, con sus majestuosos glaciares, sus encantadores lagos e inmensas selvas vírgenes, brindan al turista lo más hermosos paseos y excursiones de media y alta montaña con panoramas llenos de hechizos y de control (De Agostini, 1946: 41-42).

El Paine ofrece extraordinarios cuadros de tal imponencia y vivacidad de colores que exceden cuanto imaginarse queda, sobre todo si se observa desde el curso inferior del río homónimo, cerca de su confluencia con el lago Maravilla, donde su cauce adquiere tanta amplitud y placidez que se asemeja un hermoso lago; no lejos ofrece además una hermosísima cascada (De Agostini, 1946: 59).

La representación del paisaje en Agostini no difiere de los registros anteriores. Por ejemplo, el carácter espectacular. Sólo que inducir el deseo del turista buscó desplazar un imaginario potente de los siglos anteriores que definía a la geografía bajo criterios negativos. La visión global de la guía, demuestra que el hombre anuló las principales dificultades y si emerge alguna traba, es el condimento de un viaje que promueve el desafío de llegar a los confines patagónicos y retratarla entre los lindes de la mirada o en los marcos de las cámaras fotográficas. El padre Agostini, afrontó los atributos de un territorio esquivo tradicionalmente, con el ordenamiento de una práctica artificial (el turismo), industria que operó dentro de un entorno seleccionado estableciendo otras lógicas de significación. Móvil que consolidó años más tarde, los mecanismos turísticos que funcionan actualmente a nivel de estructura y publicidad.

\section{La difusión del turismo regional en el trabajo de los agentes locales: Touring Club}

En la historia oficial del Parque Nacional Torres del Paine se destacan las primeras exploraciones (incluye el viaje inglés) y los sucesivos propietarios que participaron del periodo ganadero (1910-1960). Desde 1959, distintos proyectos intentaron fortalecer el cuidado de la naturaleza y ampliar el número de hectáreas para la conservación del hábitat del parque. Actualmente la administración está a cargo de la Corporación Nacional Forestal (CONAF).

La semblanza anterior, omite la participación local en la definición del parque dentro de un conjunto coordinado más amplio de servicios turísticos, fijar sus accesos y difundir los paisajes de la región. Una de las entidades más productiva en estas materias fue el Touring Club, dirigido por el 


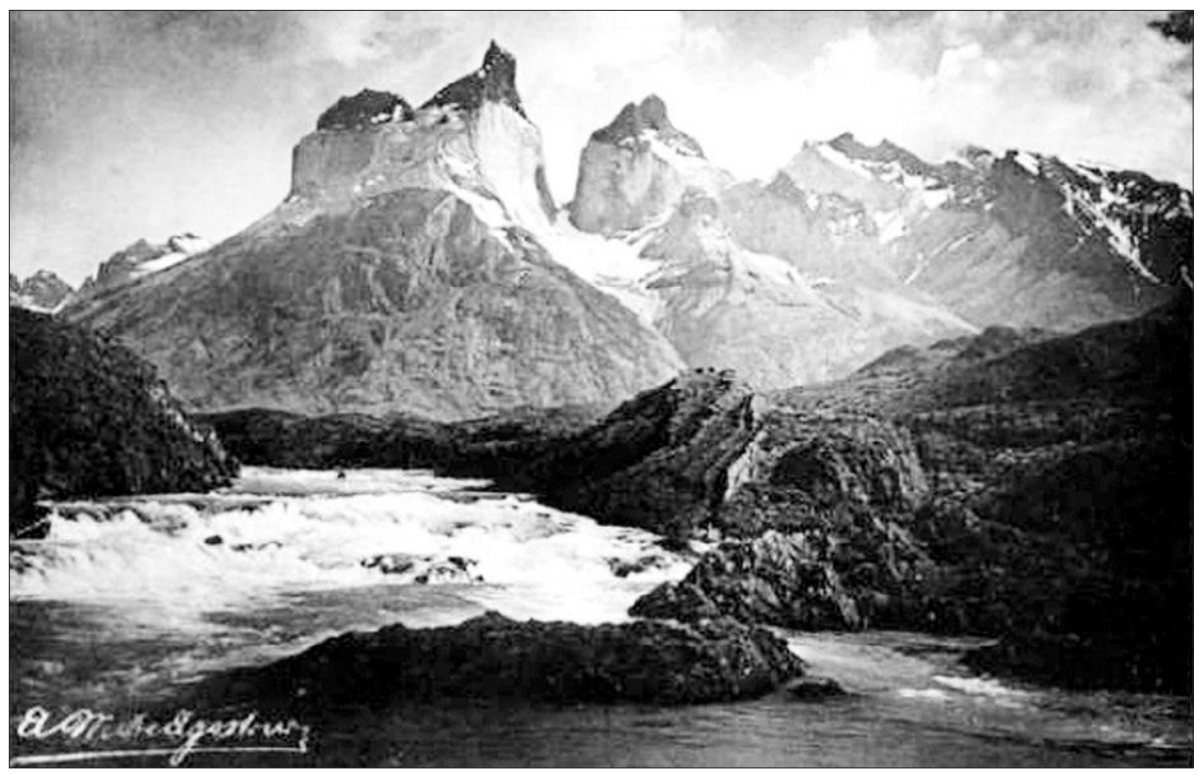

Fig.2. Fotografía del Paine, por Alberto María de Agostini.

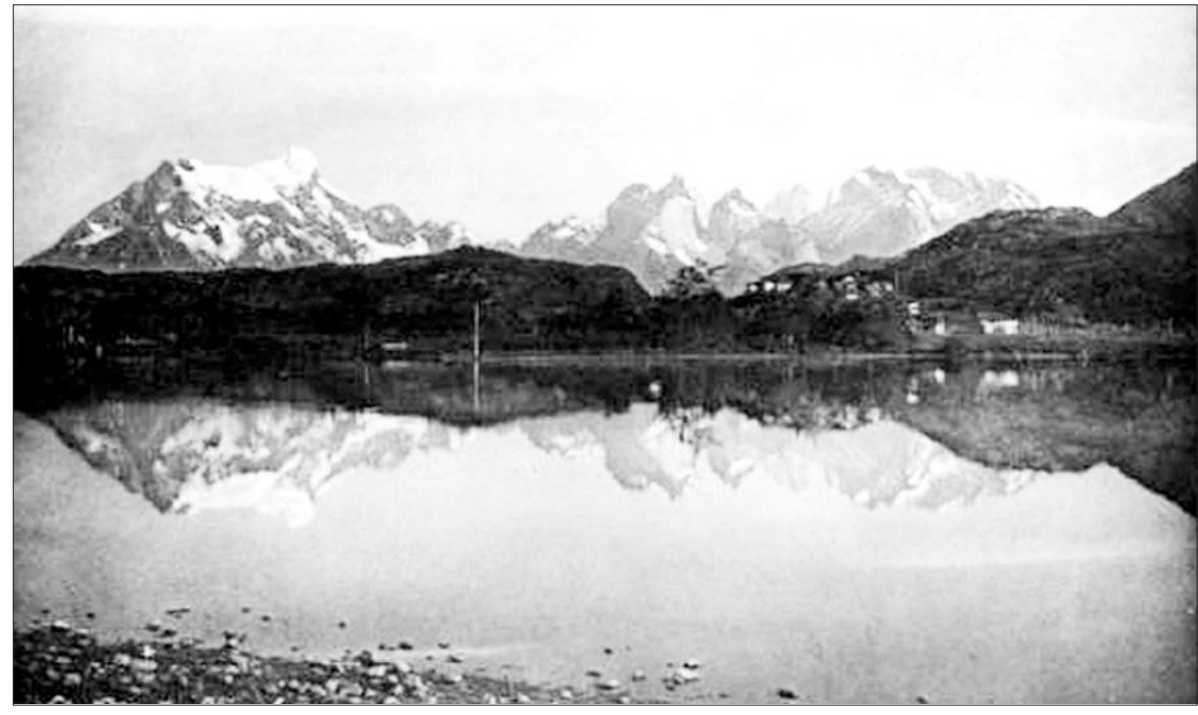

Fig.3. Fotografía del Paine, por Alberto María de Agostini.

inmigrante alemán Werner Gromsh, que recogió la inquietud de los habitantes de Punta Arenas de suplir -en los años 30- la carestía de políticas públicas en las áreas del transporte y el turismo. El objetivo del organismo era llamar la atención del gobierno central, respecto a la importancia de desarrollar una industria turística en la región. Sus principales peticiones confluían en crear una red de parques para la explotación turística en los terrenos fiscales, diseñar una estructura acorde con este cometido, promulgar una ley de impuesto al turismo (fondo autónomo regional) y finalmente, apoyar la inversión privada con una exención de impuesto (Ferrer, 2009:125:154). En 1932, el Touring Club ya difundía en los diarios locales, la idea de crear un parque con fines turísticos en los espacios actuales del PNTP -adelantados a los planes de las autoridades centrales-. Incluso el 


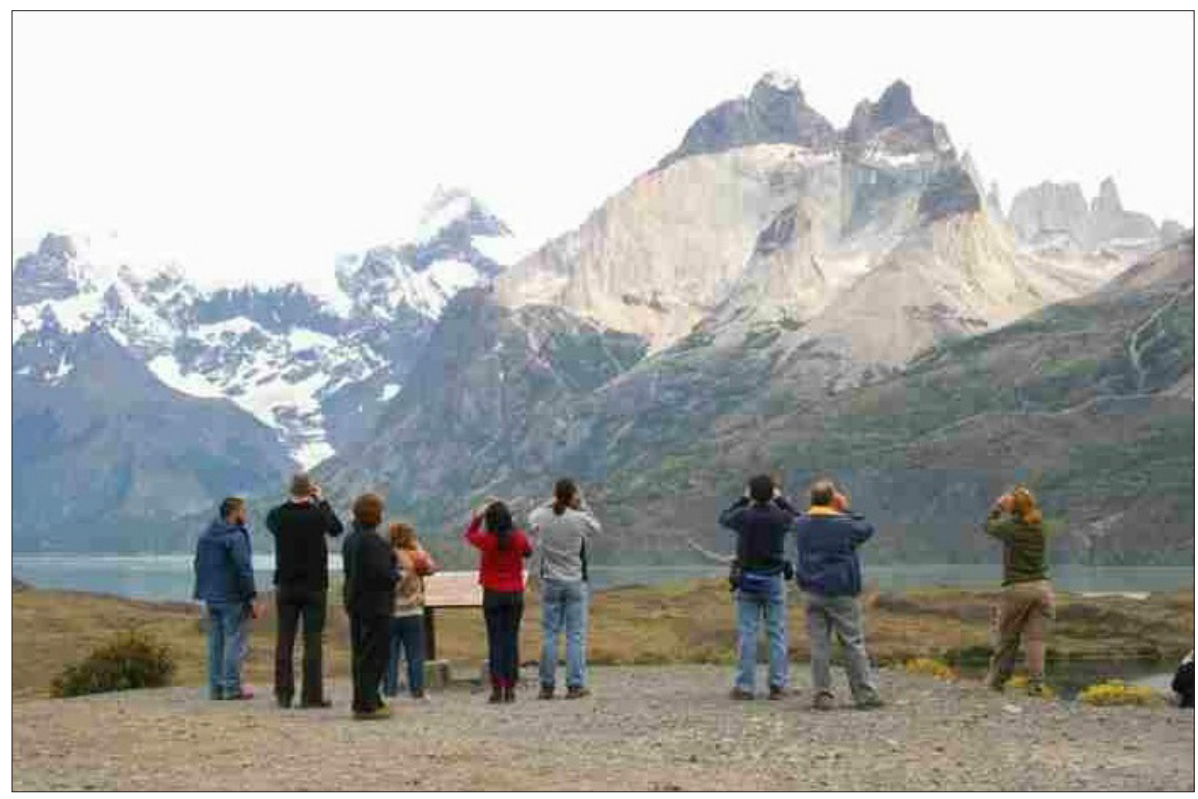

Fig.4. Turistas fotografiándo los cuernos del Paine. En: www.visitechile.com.

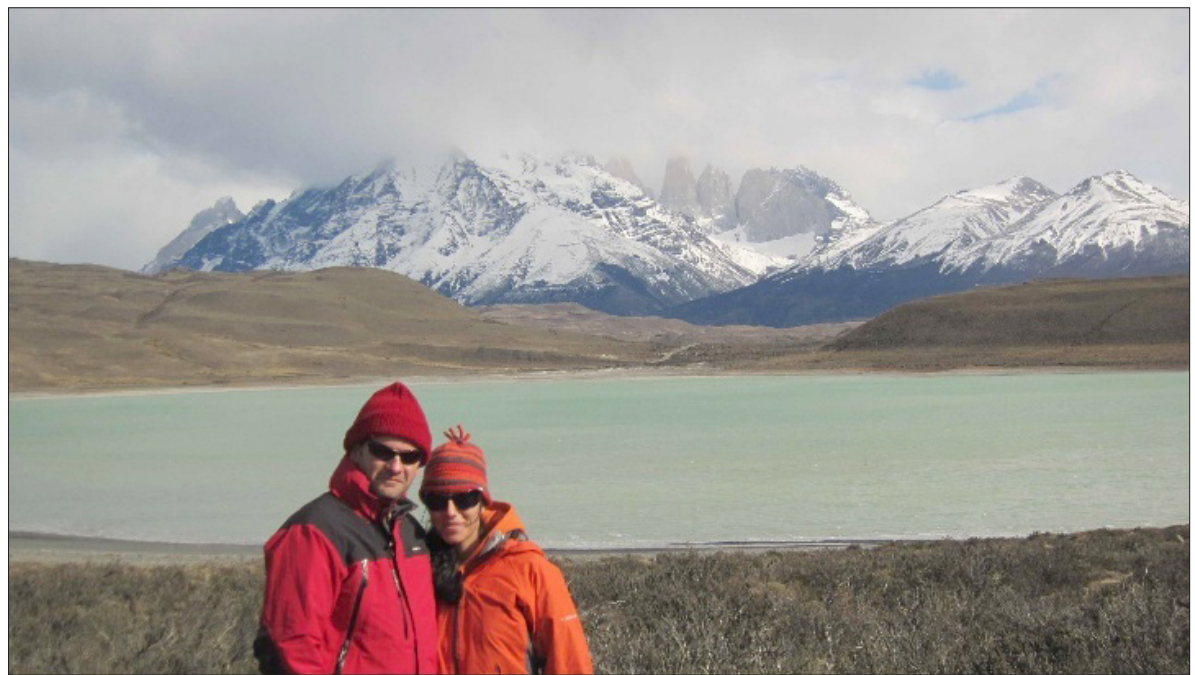

Fig.5. Turistas posando, en el fondo las Torres del Paine. En: www.acrossargentina.com.

proyecto de 1959 del Parque Nacional del Turismo Lago Grey, fue fruto de los esfuerzos coordinados del Touring Club con la comunidad local.

Las publicaciones del Touring Club apuntaban a la coordinación y difusión de las prestaciones turísticas vigentes a las personas que visitaban Magallanes (la guía se repartía en los barcos). Si comparamos un folleto de 1938 y 1959, observamos en el primero, una propagación incipiente del turismo en la región. Se destacaba la ciudad de Punta Arenas como una ciudad novedosa con una construcción elegante y sobria. En general, el trayecto propuesto combinaba lo urbano (reparticiones públicas, museos, cementerio, etc.) con la naturaleza y el mundo del trabajo (las estancias y el frigorífico). El viaje terrestre era una elección todavía marginal por las escasas millas de carretera en buen estado. 
En tanto, la travesía por el mar presentaba una oferta turística más concreta para el Touring Club, que coordinó los viajes hacia los fiordos de tierra del Fuego en asociación con la empresa de vapores durante el mes de febrero. La ruta entre Magallanes y la provincia de Última Esperanza no era muy propagada porque los servicios asociados que difundía el Touring Club, estaban situados en lugares más cercanos a la ciudad de Punta Arenas. En cambio la publicación de 1959, introduce el relato histórico de la fundación de Punta Arenas unido a la presentación de otras ciudades de la región (Porvenir y Puerto Natales). El folleto fue dividido entre el turismo terrestre y marítimo. En el primero, se propuso al visitante conocer el primer vestigio de soberanía de Chile en la región (fuerte Bulnes), el museo salesiano (Maggiorino Borgatello), el frigorífico en Tres Puentes y los entornos del Paine. La principal diferencia con la publicación de 1938, fue el desplazar la táctica de nombrar los lugares mediante el uso descriptivo, por una estrategia de apelación (público objetivo: el turista); así se reduce la diversidad geográfica, lo que demuestra una mayor madurez del sistema turístico en la región a fines de la década de los cincuenta.

En el apartado turismo marítimo (1959), abundan las menciones sobre lo extraordinario y único de la composición geografía de la Patagonia (fiordos, islas y ventisqueros). Espacios que en los últimos años, son ofertados en los paquetes turísticos en la meta tal vez, de diversificar el mercado ante el posible desgaste del PNTP por la falta de conciencia de las autoridades de frenar la carga de visitas, cuyos estragos como los incendios o la sobrepoblación en algunos puntos del parque, puedan dañar definitivamente la imagen de soledad, belleza y aventura difundida en el extranjero. El retrato fotográfico presentado por el folleto, mejoró su calidad e incorpora tanto los macizos del Paine como los heterogéneos bordes marítimos. Finalmente, lo interesante de rescatar ambas guías turísticas, fue advertir por un lado, la caída en desuso de muchos de los atractivos difundidos (el criadero de zorros, Chabunco, mina Loreto, etc.), o bien la constancia de espacios sólo para la recreación local porque no lograron completar el proceso de turistificación de sus entornos, tal es el caso de Chabunco, la laguna de patinar, el regimiento
Pudeto, río Seco, por mencionar algunos.

\section{CONCLUSIONES}

Las lecturas vinculantes entre el discurso del turismo y la inscripción de la Patagonia turística, contienen una línea diferenciada de formas representativas imposible de agrupar en una perspectiva homogénea de circunstancias y definiciones. La participación de múltiples prácticas sociales y antecedentes discursivos complejiza aún más la comprensión reciente de una Patagonia desde el turismo o la producción económica. En ambos criterios, se abordan los atributos más sobresalientes del territorio, uno atento a las particularidades del paisaje, el otro a la calidad y cantidad de recursos naturales.

No es nada nuevo en la historia social de la Patagonia la insistencia de relatos que sitúan cualidades de la geografía y sus habitantes. El esfuerzo está ahora en advertir, los procesos de expansión de ciertas lógicas de valoración que posicionan a la Patagonia dentro del criterio turístico. En ese sentido, el debate de los parques nacionales nos pareció de gran importancia, porque desde ahí, se comenzó a pensar la posibilidad de cuidar la naturaleza en función de un proyecto de crecimiento económico aún incipiente en el siglo XX. El paralelo entre Chile y Argentina fue la tribuna para mostrar que el sistema turístico se caracteriza por su heterogeneidad, ya que cada país (incluso cada destino turístico), supone situaciones diferenciadas coparticipantes en la significación del turismo en la Patagonia.

Por ejemplo, Chile ingresó en el debate del cuidado de la naturaleza en cuanto necesitó encontrar soluciones concretas en el aprovechamiento útil y racional de sus recursos naturales. En dicho trayecto, los primeros parques nacionales se formularon en los terrenos "inútiles" (laderas sin acceso al ferrocarril o no aptos para la colonización) para el Estado. En cambio en Argentina, los intelectuales como Francisco Moreno, estuvo más influenciado por el sentido conservacionista norteamericano de delimitar un espacio geográfico intocable, testimonio palpable donde fortalecer el carácter identitario de la nación.

No obstante, la visibilidad de la Patagonia turística no sólo fue partícipe de las acciones de una 
política pública. Nos pareció interesante integrar también, un panorama general de otras prácticas sociales en el ámbito de la participación de la comunidad local y las exploraciones territoriales como antecedentes del crecimiento turístico en la Patagonia; aparte de entregar señales particulares en el plano representativo del paisaje. Tal es el caso del diario de Florence Dixie, escrito que narró la experiencia de viaje del grupo, ocupando un tono paradisíaco y de exaltación, que delimitó lo bello dentro del área del Paine. El interés particular en un fragmento territorial en éste relato, transformó las valoraciones negativas de las representaciones anteriores.

El turismo desarrolló por medio del conjunto de miradas un objeto turístico, porque la reiteración finaliza el proceso de turistificación de un lugar indicado. No es extraño entonces, la citación recursiva de retratos y mensajes publicitarios en canales como las agencias de viajes, revistas de viajes $e$ instituciones turísticas gubernamentales. Instituciones y medios que utilizan y concentran en ideas sintéticas qué imagen de la Patagonia debe mostrarse al mundo y cuáles son los sujetos convocados a visitarla.

En resumen, la trascendencia del turismo en la Patagonia durante el siglo XX, abarcó la transformación valorativa del territorio que posicionó el paisaje dentro de un sistema económico incipiente que, a nivel de representación desplazó o afirmó atributos. Además de los cruces entre lo estético, lo mercantil, la entretención, etc., que fueron partícipes de una movilidad de sentido o bien, de un retroceso por el carácter diferenciado de los enfoques presentados.

\section{BIBLIOGRAFÍA}

Barreto, M. (2007). Turismo y cultura. Relaciones, contradicciones y expectativas. Tenerife. España: ACA y PASOS, RTPC.

Bertoncello, R. (2006). Turismo, territorio y sociedad. El "mapa turístico de la Argentina". En A. Geraiges de Lemos y otras, América Latina: cidade, campo e turismo. (317-335). San Pablo-Brasil: CLACSO.

Booth, R. (2010). El paisaje aquí tiene un encanto fresco y poético. Las bellezas del sur de Chile y la construcción de la nación turística. Hib. Revista de Historia Iberoamericana, 3 (11), 10-32. Recuperado de http://www.revistahistoria.universia.cl/pdfs_revista/ articulo_112_1285888012302.pdf

Cabezas, Á. (1988). Aspectos históricos de la legislación forestal vinculada a la conservación, la evolución de las áreas silvestres protegidas de la zona de Villarrica y la creación del primer parque nacional de Chile. Santiago: Corporación Nacional Forestal.

Camus, P. (2008). Federico Albert: Artífice de la gestión de los bosques de Chile. Revista de Geografía Norte Grande, (30), 55-63. Santiago: Pontificia Universidad Católica de Chile.

Casals, V. (1999). La política forestal en Chile. Una perspectiva histórica. Scripta Nova, 16 (45). Recuperado de http://www.ub.ed/geocrit/sn-45-16.htm

Cohen, E. (2005). Principales tendencias en el turismo contemporáneo. Política y Sociedad, 42 (1), 11-24. España: Universidad Complutense de Madrid.

Corporación Nacional Forestal. Estadística visitantes unidad SNASPE. Recuperado de http://www.conaf.cl/wp_ content/files_mf/1385733297

De Agostini, A. (1946). Guía Turística de Magallanes y Canales Fueguinos. Punta Arenas: [s.n], Buenos Aires: Isa de Vicente.

Digues, A. (2005). El mito moderno de la naturaleza intocada. Sao Paulo-Brasil: NUPAUB-USP.

Dixie, F. (1996). A través de la Patagonia. Punta Arenas: Ediciones Universidad de Magallanes.

Ferrer, D. (2009). El conocimiento geográfico de la Patagonia interior y la construcción de la imagen de Torres del Paine como patrimonio natural a conservar. Estudios Geográficos, LXX (266), 125-154. Recuperado de http://www.estudiosgeograficos.revista.csic.es

Fortunato, N. (2005). El territorio y sus representaciones como recursos turístico. Valores fundacionales del concepto de "parque nacional". Estudios y perspectivas en Turismo, 14, 314-348. Argentina: Centro de Investigaciones y Estudios Turísticos.

Gay, C. (2 de abril de 1838). Ministerio del Interior. Viaje científico: sobre las causad de la disminución de los bosques en la provincia de Coquimbo. El Araucano, 38 (39). Santiago: Imprenta de la opinión.

Hiernaux, D. (2002). ¿Cómo definir el turismo? Revista Aportes y Transferencias, 2 (2), 13-27. Mar del Plata: Universidad del Mar del Plata.

Iglesia, J. (2003). La doctrina de conservación de los montes. Claudio Gay y la conformación de un pensamiento ambiental en Chile a mediados del siglo XIX. Simposio de Historia Ambiental Americana. Santiago: Universidad de Chile. 
Jafari, J. (2005). El turismo como disciplina científica. Política y Sociedad, 42(1), 39-56. España: Universidad Complutense de Madrid.

Louis, C., \& Troncoso, C. (2005). "Conocer la patria es un deber": Promoción turística en las páginas de Visión de Argentina (1950). GEOUSP-Espaço e Tempo, 17, 185.

Navarro, P., \& Vejsberg, L. (2009). El proyecto turístico barilochense antes de Bustillo entre la prehistoria del Parque Nacional Nahuel Huapi y el desarrollo local. Estud. Perspect. Tur, 18(4), 414-433. http://www. scielo.org.ar/scielo.php?script=sci_arttex\&pid=s1851$73220090004000004 \%$ ing $=e$ \% $\%$ rm $=$ iso $>$.

Navarro, P. (2008). El proceso de construcción social de la región de Nahuel Huapi en la práctica simbólica y material de Exequiel Bustillo (1934-1944). Revista Pilquén. Año IX (9), 2-14. Viedma: Universidad Nacional de Comahue, Sección Ciencias Sociales.

Navarro, P. (2008). La comisión del paralelo 41 y los límites del "progreso" liberal en los territorios nacionales del sur argentino. Scripto nova, XII (264). Recuperado de http://www.ub.edu/geocrit/nova.htm

Nuñez, P., \& Vejsberg, L. (2010). El turismo, entre la actividad económica y el derecho social. El Parque Nahuel Huapi, Argentina 1934-1955. Estudios y perspectivas en Turismo, 19 (6), 930-945. Buenos Aires, Argentina: Centro de Investigaciones y Estudios Turísticos.
Piglia, M. (2007). El "despertar del turismo": primeros ensayos de una política turística en la Argentina (1930-1943). I Congreso Latinoamericano de Historia Económica. Montevideo.

Sancho, A., \& Duhalis, D. (1998). Introducción al turismo. Madrid: Organización Mundial del Turismo.

Scarnazella, E. (2002). Las bellezas naturales y la nación: los parques nacionales en Argentina en la primera mitad del siglo XX. Revista Europea de Estudios Latinoamericanos y del Caribe, (73), 3-20. Ámsterdam: CEDLA, Centro de Estudios y Documentación Latinoamericanos.

Troncoso, C., \& Louis, C. (2005). Conocer la patria es un deber: promoción turística en las páginas de Visión de Argentina (1950). GEOUSP. Espaco e Tempo. (17), 185-205. Sao Pablo: Universidad de Sao Pablo.

Touring Club de Magallanes (1938). Guía Turística y Comercial. Punta Arenas: Imprenta Juguslava.

Touring Club de Magallanes (1959). Magallanes: Zona de turismo. Santiago: Imprenta el Imparcial.

Urry, J. (2002). The tourist gaze. London: Sage publications

Zusman, P. (2011). Panamericanismo y conservacionismo en torno al viaje de Theodore Roosevelt a la Argentina (1913). Modernidades. La historia en diálogo con otras disciplinas, 1 (11), año 6. Recuperado de http://www. publicaciones.ffyh.unc.educ.ar/index.php/modernidades. 